Acta vet. scand. 1988, 29, 9-13.

From the National Veterinary Institute, Kuopio, Public Health Laboratory, Kuopio, Finland, and WHO Collaborating Centre for Reference and Research on Pneumococci,

Statens Seruminstitut, Copenhagen, Denmark.

\title{
Streptococcus Suis Isolated from Pigs in Finland
}

\author{
By L. Sihvonen, D. N. Kurl and J. Henrichsen
}

\begin{abstract}
Sihvonen, L., D. N. Kurl and J. Henrichsen: Streptococcus suis isolated from pigs in Finland. Acta vet. scand. 1988, 29, 9-13. - A total of 58 Streptococcus suis strains were isolated from deceased pigs submitted to the National Veterinary Institute, Regional Laboratory in Kuopio, Finland, over a $31 / 2$ year period, most frequently from cases of pneumonia. The bacteria were isolated from cases of meningitis, sepsis, rhinitis, endocarditis and abortion. S. suis was also isolated from nasal cavity, lung and brain of some sick piglets without signs of inflammation. Further S. suis was detected in 12 out of 107 tonsils of healthy fatteners tested.

S. suis strains were identified by biochemical methods followed by typing. The most common capsular types were 7, 3 and 2, respectively. Only one type 1 strain and no types 6 and 9 strains were found. All S. suis strains tested were sensitive to penicillin and ampicillin.

S. suis is not uncommon in Finnish pig herds. S. suis may be regarded as a potentially pathogenic organism which under certain predisposing conditions may cause serious disease.
\end{abstract}

Streptococcus suis; different serotypes; pathological changes; healthy carriers.

\section{Introduction}

Streptococcus suis is an important pig pathogen which is associated with bronchopneumonia, meningitis and less frequently with a variety of other conditions (Sanfrod et al. 1982, Homme et al. 1984). This species originally contained two serotypes, 1 and 2 (Windsor \& Elliot 1975) which corresponded to serogroups $S$ and $R$ described in 1963 by de Moor. More recently new serotypes have been added to the original ones by Perch et al. (1983).

We report here the isolation and identification of S. suis belonging to different types, and their association with pathological changes, and their carriage in Finnish pigs.

\section{Materials and methods}

Bacterial strains were isolated from deceased pigs received during the last $31 / 2$ years at the National Veterinary Institute, Regional Laboratory in Kuopio. Samples of liver, spleen, lungs, brain and intestine were cultured routinely and additional cultures were performed from organs exhibiting signs of infection. About 200 lungs with some suspected macroscopic changes were also received for control of infectious diseases and therefore, cultured. 107 tonsils, 12 nasal swabs and 25 lungs from healthy fatteners in slaughter house (spring-summer 1986) were also cultured. Each tonsil was sampled separately by scraping deep into the tissue with 
sterile scalpes. Samples from fatteners were cultivated within a few hours of slaughter. Primary isolation was made on calf blood agar plates which were incubated aerobically at $37^{\circ} \mathrm{C}$ for $48 \mathrm{~h}$. Small colonies with $\alpha$ - or $\beta$-hemolysis were examined by use of a variety of established procedures: gram strain, catalase test, survival at $60^{\circ} \mathrm{C}$ for $30 \mathrm{~min}$. Api 20 Strep system (Le Balme Les Grottes), Streptex system (Welcome Reagents Limited) and growth in $6.5 \% \mathrm{NaCl}$ broth.

$\mathrm{HCl}$ Lancefield and Rantz \& Randall (1955) extracts of strains were examined in Kuopio using commercial antisera specific for groups $\mathbf{R}$ and $\mathbf{S}$ (Wellcome Reagents Limited) in a gel-diffusion test with reference strains belonging to types 1,2 and $1 / 2$ as controls. Strains were later examined with anti-type $1-11$ antisera at the Statens Seruminstitut in Copenhagen (Perch et al. 1983) by means of both the capsular reaction test carried out using $6 \mathrm{~h}$ Todd-Hewitt broth cultures (Lund \& Henrichsen 1978), and the capillary precipitation test using $0.1 \mathrm{~N} \mathrm{HCl}$ Lancefield extracts (Perch et al. 1983).

A total of 35 strains was tested for antimicrobial sensitivity using the disk diffusion technique (Rosco).

\section{Results}

Seventy strains were identified as S. suis. They were catalase-negative, Gram positive cocci that did not grow on blood agar after $30 \mathrm{~min}$ at $60^{\circ} \mathrm{C}$ or in $6.5 \% \mathrm{NaCl}$; they all showed homogenous growth in broth and were $\alpha$-haemolytic on calf blood agar with the exception of one strain which was $\beta$-haemolytic on primary isolation.

Sixty-four of the $70 \mathrm{~S}$. suis strains were identified as S. suis with the Api 20 Strep index and the extended data base. Six strains gave a doubtful or unacceptable profile. The typical characteristics of $S$. suis, namely arginine dihydrolase, inulin and raffinose, gave fewer positive results than expected. Eleven strains $(16 \%)$ were arginine dihydrolase negative. Inulin was negative for 20 strains (29\%), raffinose for 9 strains (13\%) and both sugars for 4 strains $(0.6 \%)$. Fifty-five strains of 70 $(80 \%)$ were esculin positive.

The group D antigen could be detected in all except 9 strains examined with Streptex using a heavy suspension of the bacterial culture. Negative strains were then checked by preparing autoclave extracts and testing them with Streptex. Positive reactions were then obtained.

Table 1. Serotypes of S. suis and their association with pathological changes.

\begin{tabular}{|c|c|c|c|c|c|c|c|c|}
\hline \multirow[t]{2}{*}{ Lesions } & \multicolumn{7}{|c|}{ Serotypes } & \multirow[b]{2}{*}{ Total } \\
\hline & 1 & 2 & 3 & 4 & 7 & None $^{a}$ & $\mathrm{Nd}^{\mathrm{b}}$ & \\
\hline Pneumonia & & 6 & 1 & & 7 & 1 & 10 & 25 \\
\hline Meningitis & 1 & & & & 2 & 2 & 2 & 7 \\
\hline Sepsis & & & & 1 & 1 & & 4 & 6 \\
\hline Rhinitis & & & 3 & & 2 & 2 & & 7 \\
\hline Endocarditis & & & 1 & & & & & 1 \\
\hline Abortion & & & & & & & 1 & 1 \\
\hline No pathological lesions & & & 2 & 2 & 5 & 2 & & 11 \\
\hline Number of strains & 1 & 6 & 7 & 3 & 17 & 7 & 17 & 58 \\
\hline
\end{tabular}

a: Not belonging to capsular types 1 to 11 .

b: Not serotyped. 
Table 2. Serotypes of S. suis isolated from healthy fatteners in slaughter house.

\begin{tabular}{lcccccccc}
\hline & \multicolumn{7}{c}{ Serotypes } & \\
\cline { 2 - 8 } & $1 / 2$ & 3 & 7 & 8 & 10 & 11 & None $^{\mathrm{a}}$ & Total \\
\hline Tonsils $\left(107^{*}\right)$ & 1 & 2 & 1 & 1 & 1 & 1 & 5 & 12 \\
Nasal cavity $\left(12^{*}\right)$ & - & - & - & - & - & - & - & 0 \\
Lung $\left(25^{*}\right)$ & - & - & - & - & - & - & - & 0 \\
\hline Number of strains & 1 & 2 & 1 & 1 & 1 & 1 & 5 & 12 \\
\hline
\end{tabular}

a: Not belonging to capsular types 1-11.

* Number of samples.

Fifty-three of the 70 strains of S. suis were serotyped. The rest were identified only biochemically as S. suis. The results with Wellcome anti-types 1 and 2 antisera were in agreement with those obtained at the Statens Seruminstitut in Copenhagen. The serotypes of S. suis found and the pathological conditions they were associated with are shown in Table 1. Serotypes 7, 3 and 2 were the most common. Seven strains were non-typable. The pigs with meningitis, sepsis and endocarditis were 1-7 weeks old, whereas those with pneumonia were 3-20 weeks old at death. S. suis was the only pathogen isolated in 11 cases of pneumonia. Enzootic mycoplasmal pneumonia was detected together with S. suis in 9 lungs. Some other bacteria, usually Pasteurella multocida, were detected from lungs together with S. suis from 8 cases of pneumonia. S. suis were isolated from 6 nasal cavities, 3 lungs and 2 brains without any unequivocal pathological lesion in the tissues. All except one of these pigs were 1-8 weeks old and they had had either enteritis or pneumonia as the fatal disease. One fattener which had been coughing, had no pathological lesion even though S. suis serotype 7 was isolated from the lungs. Serotypes of S. suis isolated from healthy fatteners in the slaughter house are shown in Table 2. Antimicrobial sensitivity of 35 S. suis strains is shown in Table 3.
Table 3. Antimicrobial sensitivity of 35 S. suis strains.

\begin{tabular}{lrrc}
\hline & & Inter- & \\
& Sensitive & mediate & Resistant \\
\hline Penicillin & 35 & - & - \\
Ampicillin & 35 & - & - \\
Cephalexin & 34 & 1 & - \\
Erythromycin & 30 & 3 & - \\
Tylosin & 27 & 8 & - \\
Lincomycin & 25 & 7 & 3 \\
Trimethoprim + sulfa & 9 & 15 & 11 \\
Tetracyclines & 3 & 17 & 15 \\
Neomycin & 2 & 4 & 29 \\
Streptomycins & 1 & 16 & 18 \\
Polymyxins & - & - & 35 \\
\hline
\end{tabular}

\section{Discussion}

Streptococcus suis is not uncommon in Finnish herds of pigs. About half of the strains from deceased pigs were isolated from lung lesions, frequently in association with other pathogens, usually Mycoplasma hyopneumoniae or Pasteurella multocida. Our findings are in agreement with other reports on the distribution of S. suis in tissues (Perch et al. 1983, Hommez et al. 1984, Vecht et al. 1985). The preponderance of S. suis from the lungs and upper respiratory tract seems clear. Healthy pigs may be tonsil carriers of S. suis (Clifton-Hadley 1984) as is shown in our study. S. suis may also be present in nasal cavities. S. suis could establish itself in 
the nasopharynx of pigs and then spread systemically, occassionally resulting in septicaemia and/or meningitis. The lungs seem to be the organ in which S. suis is most frequently found. S. suis may sometimes be an opportunistic and somewhat innocuous secondary invader of the lung. Some of our pigs had primary enzootic mycoplasmal pneumonia and S. suis as a secondary invader. However, on some lungs S. suis was the only isolate. S. suis was isolated from rhinitis in some cases, whereas in other cases it was found in mixed culture in nasal cavities without lesions. The role of S. suis in the aetiology of rhinitis is very unclear. The cases of endocarditis and abortion were sporadic. We did not isolate $\mathrm{S}$. suis from cases of arthritis. Only a few cases were associated with arthritis in the Danish and Belgian herds of pigs also (Hommez et al. 1983, Hommez et al. 1984).

The biochemical reactions of the isolates were not uniform, with the exception of their inability to grow in $6.5 \% \mathrm{NaCl}$ and on blood agar after $30 \mathrm{~min}$ at $60^{\circ} \mathrm{C}$. The Api 20 Strep system gave good identification in $91 \%$ of S. suis strains. The results are similar with those of Hommez et al. (1986). The Api 20 Strep system can be improved by giving more attention to strains which do not posses arginine dihydrolase or the enzyme necessary for the fermentation of inulin and raffinose. Such strains might belong to S. suis. Quite many strains were inulin $(29 \%)$ or raffinose $(13 \%)$ negative. However, very few strains $(0.6 \%)$ were negative in both sugars. The Api 20 Strep system together with no growth in $6.5 \% \mathrm{NaCl}$ and on blood agar after $30 \mathrm{~min}$ in $60^{\circ} \mathrm{C}$ are good preliminary tests for identification of $\mathrm{S}$. suis. The determination of the group D antigen of S. suis with Streptex is not as reliable as it should be. All strains did not give positive reaction in Streptex, even though heavy suspension of bacteria was used. However, autoclave extracts gave positive reactions with Streptex and could also be used for typing.

S. suis serotypes 1 and 2 are known to cause meningitis and arthritis in piglets (Windsor \& Elliot 1975). More recently S. suis has been isolated from pneumonia and less frequently from a variety of other conditions in pigs and new serotypes have been described (Perch et al. 1983). Probably more serotypes will be encountered in the future if looked for among strains identified as S. suis according to the fermentation pattern; the key reactions being arginine, inulin and glycogen positive and VP negative. In our material, type 7 was the most frequently isolated from pigs followed by types 3 and 2. Type 2 was found only in association with pneumonia which is in accordance with the findings of others (Perch et al. 1983, Hommez et al. 1984). In Britain type 2 is mostly associated with meningitis, septicaemia and arthritis (Clifton-Hadley 1984). Types 1 and 4 are rare among our pig isolates. The detectable tonsillar carrier rate of $\mathrm{S}$. suis was $11 \%$ in our study. Pigs according to Clifton-Hadley (1984) may be carriers for prolonged periods of time and invasive disease in susceptible animals may be spread from carriers.

The incidence of disease associated with S. suis is low in Finnish herds of pigs. However, on certain farms it does cause problems. Such farms have a high population density, poor hygiene and poor ventilation as well as many other stress factors. Careful observation and early treatment of clinical cases with penicillin are recommended in these farms together with improvement of environmental conditions. 


\section{References}

Clifton-Hadley FA: Studies of Streptococcus suis type 2 infection in pigs. Vet. Res. Comm. 1984, 8, 217-227.

Clifton-Hadley FA, Alexander TJL, Upton I, Duffus WPH: Further studies on the subclinical carrier state of Streptococcus suis type 2 in pigs. Vet. Rec. 1984, 114, 513-518.

Hommez J, Castryck F, Devriese LA, Henrichsen $J$ : Prevalence of Streptococcus suis and methods of identification. In: M. Pensaert et al. (Editors), Proc. 8th I.P.V.S. Congress, Ghent, Belgium 1984, p. 134.

Hommez J, Devriese LA, Henrichsen J, Castryck $F$ : Identification and characterization of Streptococcus suis. Vet. Microbiol. 1986, 11, 349355.

Lund E, Henrichsen J: Laboratory diagnosis, serology and epidemiology of Streptococcus pneumoniae. In: Bergan, T. and Norris, J. R. (Editors): Methods in Microbiology, Vol. 12. Academic Press, New York 1978, pp. 241-262.

Perch B, Pedersen KB, Henrichsen J: Serology of capsulated streptococci pathogenic for pigs: six new serotypes of Streptococcus suis. J. clin. Microbiol. 1983, 17, 993-996.

Rantz LA, Randall E: Use of autoclaved extracts for haemolytic streptococci grouping. Stanford Med. Bull. 1955, 13, 290-291.

Sanford SE, Tilker AME: Streptococcus suis type II-associated disease in swine: observation of a one-year study. J. Amer. vet. med. Assoc. $1982,181,673-676$.
Vecht U, van Leengoed, LAMG, Verheigen ERM: Streptococcus suis infections in the Netherlands (Part I). Vet. Quarterly 1985, 7, 315321.

Windsor RS, Elliot SD: Streptococcal infection in young pigs. IV. An outbreak of streptococcal meningitis in weaned pigs. J. Hyg. 1975, 75, 69-78.

\section{Sammanfattning}

Isolering av Streptococcus suis från grisar $i$ Finland.

Inalles 58 Streptococcus suis stammar isolerades under 3 1/2 år från grisar sända till Statens veterinärmedicinska anstalts regionallaboratorium $i$ Kuopio, Finland. Stammarna påvisades oftast hos grisar med pneumoni. S. suis påvisades också hos grisar med meningit, sepsis, rinit, endokardit och abort. S. suis isolerades också från näshåla, lungor och hjärna hos sjuka grisar utan tecken på infektion. S. suis isolerades också från 12 av 107 tonsiller hos friska gödsvin.

S. suis stammar identifierades med biokemiska tester och typing. De vanligaste kapseltyperna var 7, 3 och 2. Endast en stam av serotyp 1 och ingen stam av serotyp 6 eller 9 kunde påvisas. Alla S. suis stammar som testades, var sensitiva för penicillin och ampicillin.

S. suis är inte ovanlig hos friska grisar. Man kan anse S. suis som en potentiellt patogen organism, som kan ge upphov till allvarliga sjukdomsfall under predisponerande förhållanden.

(Received July 9, 1987).

Reprints may be requested from: Liisa Sihvonen, National Veterinary Institute, P.O. Box 368, 00101 Helsinki, Finland. 
